\title{
Transition Countries And New Public Management: The Case Of Slovenia
}

\author{
Stanka Setnikar-Cankar, (E-mail: stanka.setnikar-cankar@fu.uni-lj.si), University of Ljubljana, Slovenia
}

\begin{abstract}
Globalisation impacts on a country and its administration with a series of economical, technological, cultural and ecological processes. The modern state is seen as a »modest« state. The state must provide the necessary direction without hindering other activities in society. The shift from public administration to new public management involves a shift in the basic design coordinates of public sector organisation. Changes in the operating of public administration require new management policies. Abolishing administrative obstacles confronted by enterprises will reduce their operating costs. An efficient and well-organised public sector is in the interest of the economy. Reorganisation of state administration operations involves setting two important goals in the strategy of reform: greater productivity and better quality of service. Operating indicators are necessary for internal and external reasons for assessing the past and planning the future. New rules on public sector operations require a preliminary definition of operational standards, which determine the extent, quality and accessibility of services, measure results and establish mechanisms impacting on both the users and payers of services.
\end{abstract}

\section{INTRODUCTION}

lobalisation presents countries with a new role, which must also be adapted to their institutions and functions. Today it is impossible to ignore that public administration must work in parallel with the private sector as globalisation, opening up to Europe and strong competition in all sectors is more and more apparent.

The notion of globalisation was taken up in modern scientific and political communications in Anthony Gidden's book, The Consequences of Modernity (1990). The work opened up the dilemma whether globalisation was really a synonym for old European cosmopolitism and its modern realisation in the form of colonisation and Eurocentrism or a new political paradigm. Otfried Hoffe distinguishes between technical, economic, cultural, artistic, political, healthcare, institutional and other forms of globalisation. Giddes and Beck on the other hand emphasis the increase of global risk and its consequences for management (Brezovšek, 2003). Globalisation is seen as a process in which the thoughts and actions of people impact more and more on the world as a whole and on changes, which accelerate communication between people, nations and cultures all over the world.

Globalisation impacts on a country and its administration with a series of economical, technological, cultural and ecological processes so the need to change definitions of the institutional role of the state and state administration is all the more clear. The modern state is seen as a »modest « state that operates optimally in harmonising different interests. The state must provide the necessary direction without hindering other activities in society. The concept of an active state is the key element in modernisation (Pikalo, 2003).

We live in an environment where operating conditions have significantly changed over the last decade both for commercial and non-commercial organisations. Practice has shown that elements leading to such an approach are to a sufficient extent present in a competitive market system. In environments, in which open and competitive market systems operate, there exist enough motivation for changes in practices. 
Due to close links and correlation which rule among economic and non-economic markets, it is impossible that changes in systems in the area of the economy would not also result in changes within the public sector.

The old emphasised regulative role of countries is now making room for new partnership roles, in which the country, together with all its social sub-systems as equal partners, is concerned with successful development.

Considerably different is the situation in activities not operating under market conditions and in which suppliers of products or services are monopolistic. In this case, there are practically no external economic forces for change in existing business practices and provision of products or services (Price Waddams, Young 2003).

The absence of the possibility of choice often deters buyers and users from demanding the desired amount of goods, higher quality, timely services, and professional and proper conduct.

One can often find such a situation in a public sector, where the complete lack of any competition and choice is characteristic of its services.

An efficient and well-organised public sector is also in the interest of the economy.

This fact is resolved in developed nations through increased participation by citizens in decision-making, leading to the development of quality, transparency, control and evaluation of public sector operations.

Public administration is becoming more important to social-economic development, although no longer as a powerful authority, but as an equal partner. With its politics, method of operating and strategic direction it can have a direct influence on the competitive advantage of companies and the economy as a whole.

\section{THE REFORM OF THE PUBLIC SECTOR}

The reform of the public sector is a process presently taking place in the developed countries of the world, as well as in countries in transition.

Developmental activities in the public sector are much more apparent in countries in transition than in developed nations. These are changes, which have been lagging behind and must be made up for in the development of democratic processes of the near past.

Public administration in Slovenia has to now been operating within the context of traditional rules. It has become necessary to increase its effectiveness.

Today the state is the biggest company in Slovenia, and like a company, the state cannot function without a good management structure. New operating rules in the public sector require prior definition of working standards that determine size, quality and accessibility of services, measuring operational results and installing mechanisms affecting service users. The nominal role of the state in a modern market economy can be linked to the following five groups of activity:

- Implementing contractual obligations and protection of property rights, where the state assists in increasing the role and importance of the market.

- $\quad$ Providing a legal basis for reducing transaction costs of players on the market and stimulating market efficiency with strategic interventions onto the market or generating the necessary information where not sufficient on the market.

- $\quad$ Providing state goods and regulating the negative external effects.

- $\quad$ Supporting macroeconomic stabilisation.

- $\quad$ Apportioning income in society using social principles. discussed.

In the following the essential characteristics of implementing new public management in Slovenia is 


\section{NEW PUBLIC MANAGEMENT}

As a doctrine, new public management points to the failures and inadequacies of public sector performance over time, and locates the problem as laying squarely in the nature and process of public sector activity and public administration. Centralised bureaucracies, waste and inefficiency in resource-use, inadequate mechanisms of accountability and redress are all problems, which the new public management seeks to address (Falconer, 1997).

The term "New Public Management" has developed as "a handy shorthand or summary describing a way of recognising that public sector bodies have to bring their management, reporting, and accounting approaches closer to (a particular perception of) business methods" (Dunleavy, Hood, 1994).

This new public management is the central belief that public service provision is improved by the introduction of the changes listed below, which serve to transform both the organisational structure of public organisation and the processes by which public services are delivered (Falconer, 1997, p. 69-70):

\section{Private Sector Styles Of Management}

An important theme within public management is that the public sector should seek, as far as possible, to behave in a more business-like manner. The recommendation is that the efficiency of public service provision is enhanced where a public sector agency conducts its affairs in accordance with business principles.

\section{Explicit Standards Of Performance}

Public management embodies the important belief that public sector organisations should increasingly be subjected to rigorous measures of performance. Subjecting public managers to performance evaluation introduces disciplinary mechanisms, which compel public sector bodies to focus on their specific responsibilities and carry out those tasks efficiently and effectively.

\section{Hands-On Professional Management}

The modern public manager should have discretion in decision making within his or her particular area of responsibility. Unlike the traditional public administrator, who operated in accordance with established rules and regulations, and who implemented the policies of government with little or no discretion and with no direct responsibility, the public manager is a much more active individual, with decision-making authority over, and responsibility for, the public service he or she delivers.

\section{Greater Competition In Public Service Provision}

Two central arguments within the public management approach are that the market is the best allocator of resources and individuals are the best judges of their own welfare. As such, market disciplines are advocated for the public sector, in line with the belief that the threat of competition and rivalry between providers fosters efficiency in service provision and choice for the consumer.

\section{Output Controls}

Allied to performance measurement in the need for a focus on results rather than processes. For too long, public sector organisations failed to concern themselves with their outputs (i.e. the quality of services). Rather, the focus was on inputs, given the political debates on public sector matters usually revolved around the question of resources. Under the new public management, the focus is shifted to that of results. 


\section{Economy In Resource Use}

Public service agencies must pay much greater attention to the way in which they use the financial and human resources at their disposal. The emphasis in the new public management is very much on cutting the cost of public service provision, while, at the same time, increasing its quality.

\section{Decentralisation}

In order to facilitate much of the above, the new public management calls for decentralisation in public sector organisation in order to form a more efficient, accountable public service. It is more efficient because smaller units of activity are better able to establish objectives and work toward achieving them more quickly and more directly.

The change from public administration to new public management is illustrated in the diagram below.

Figure 1: From Traditional Public Administration To New Public Management

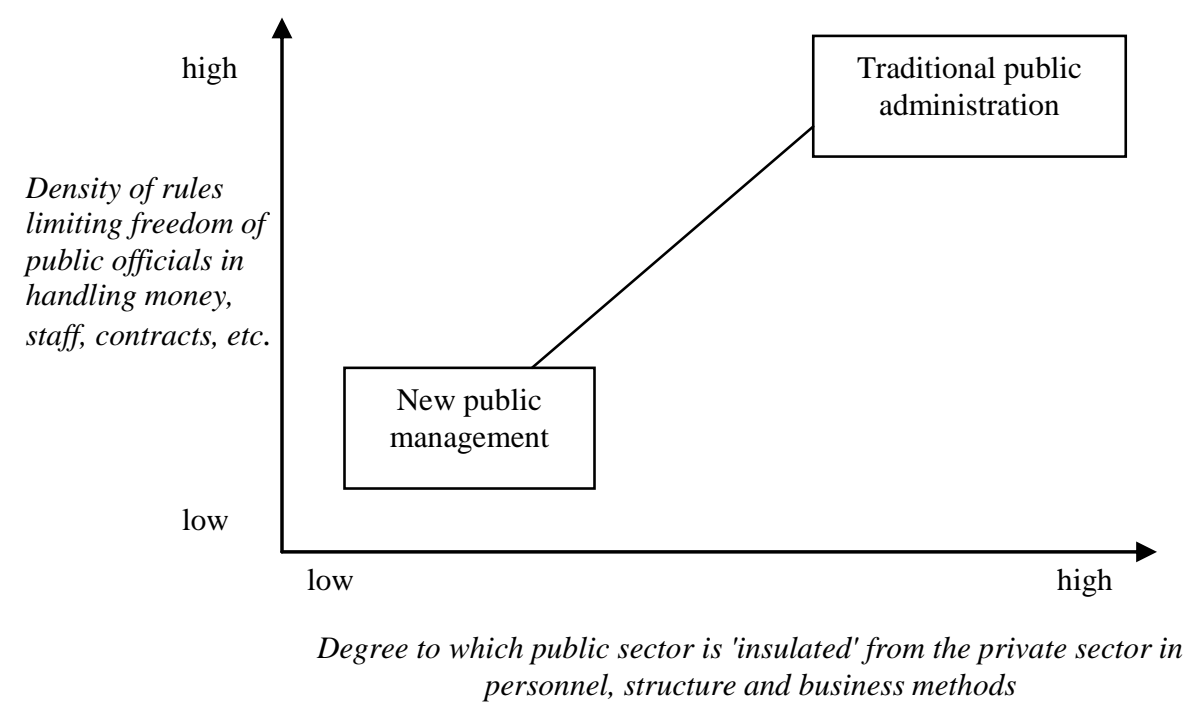

Source: Falconer, 1997, page 71.

The shift from public administration to new public management involves a shift in the basic design coordinates of public sector organisation. On the one hand, the public sector becomes less distinctive from the private sector, while on the other hand the degree of discretionary power (particularly over staff, contracts and money) enjoyed by public managers is increased, as the procedural rules emanating from the centre are relaxed. More specifically, this shift consists of (Dunleavy, Hood, 1994):

- $\quad$ Reworking budgets to be transparent in accounting terms, with costs attributed to outputs not inputs, and outputs measured by quantitative performance indicators.

- Viewing organisations as a chain of low-trust principal/agent relationships, a network of contracts linking incentives to performance.

- Disaggregating separable functions into quasi-contractual or quasi-market forms, particularly by introducing purchaser/provider distinctions.

- $\quad$ Opening up provider roles to competition between agencies or between public agencies, firms and not-forprofit bodies. 
- De-concentrating provider roles to the minimum-feasible sized agency, allowing users more scope for exit from one provider to another, rather than relying on voice options to influence how public service provision affects them.

\section{THE EFFICIENCY OF STATE ADMINISTRATION}

Public administration represents the nucleus of the information mechanism of the state that perceives, receives and processes information and makes decisions based on it for the needs of the whole system. On this basis all organs of state - the legislature, the executive (government) and the civil service - operate and make decisions. If public administration does not function properly, its deficiencies are felt throughout the whole system.

Administrative procedures exist in all countries. It is legitimate for governments to control or even screen some activities and investors who are going to install on their territory. Arguments explaining the presence of these procedures are security, protection of the environment, health protection, and quality control.

Internationalisation of the economy is closely connected with the efficient functioning of public administration. Countries differ quite significantly in the manner in which they regulate business entry and operations. Excessive regulation can lead to substantial delays and costs to firms that may decide to locate elsewhere or operate in the informal sector. Lost revenues can lead to a sub-optimal equilibrium and lower public utility.

There are three main groups of administrative procedures for enterprises: entry approvals, access to land, site development, utility connections and operational requirements. Evidence on administrative procedures in selected countries show differences between them.

The data reveal considerable variations in the number of administrative procedures as well as the time and monetary costs associated with them across countries. It is possible to see that the number of steps reflects the public interest theory through which government protects its citizens, while delays and costs can be viewed in the public choice theory as a rough indicator of the government's capacity or willingness to respond to investors' requests (Morisset, Neso, 2002 and Setnikar-Cankar, Pevcin, 2002).

Table1: Administrative Procedures In Selected Central And Eastern European Countries In Transition In 1999 And 2000

\begin{tabular}{|c|c|c|c|c|c|c|}
\hline & \multicolumn{3}{|c|}{ Number Of Procedures } & \multicolumn{3}{c|}{ Monetary Costs (US \$) } \\
\hline & Entry & Land, Site & Operations & Entry & Land, Site & Operations \\
\hline Armenia (2000) & 13 & 45 & 10 & 84 & 4414 & 75 \\
\hline Bulgaria (2000) & 29 & 40 & 19 & 291 & 233 & - \\
\hline Czech Rep. (1999) & 11 & - & - & 447 & - & - \\
\hline Latvia (1999) & 17 & 19 & - & 367 & 5885 & - \\
\hline Lithuania (1999) & 10 & 22 & 9 & 139 & 1550 & - \\
\hline Romania (2000) & 10 & 42 & - & 154 & 22523 & - \\
\hline Slovenia (2000) & 12 & 30 & 7 & 2895 & - & - \\
\hline
\end{tabular}

Source: Morisset, Neso, 2002

A country where it takes excessive time and costs to accomplish all the procedures necessary to establish and operate a business will see its potential investors lose money and decide to locate elsewhere or cancel their investment projects.

The aggregate time and fees spent by local and foreign investors are presented in table 2. Total costs are defined as delays (converted into monetary costs) plus direct costs associated with administrative procedures in each country. Delays have been converted into monetary costs assuming that opportunity costs for local investors are equal to the number of days multiplied by the daily GDP per capita in the country. For foreign investors the daily average GDP per capita in OECD countries has been used. 
Table 2: Total Costs Per Procedure In US\$ In Selected Countries

\begin{tabular}{|c|c|c|c|}
\hline \multicolumn{2}{|c|}{ For Local Investors } & \multicolumn{2}{c|}{ For Foreign Investors } \\
\hline Czech Rep. & 243 & Czech Rep. & 869 \\
\hline Armenia & 326 & Latvia & 1229 \\
\hline Bulgaria & 405 & Armenia & 1366 \\
\hline Lithuania & 449 & Lithuania & 1850 \\
\hline Latvia & 540 & Slovenia & 2363 \\
\hline Slovenia & 1535 & Bulgaria & 6023 \\
\hline Romania & 2530 & Romania & 6207 \\
\hline
\end{tabular}

Source: Morisset, Neso, 2002.

The ranking per country indicates that Romania and Slovenia are relatively expensive for their local investors, where total administrative costs can exceed US\$ 1,000 per procedure. The total administrative costs for foreign investors are relatively low in the Czech Republic and Latvia. They are very high in Bulgaria and Romania, where they can exceed US\$ 6,000 per procedure.

\section{THE REFORM OF PUBLIC ADMINISTRATION IN SLOVENIA}

Evidence listed above shows that in 2000 Slovenia was among the countries with the highest administrative barriers to investment, especially in monetary terms.

The Republic of Slovenia started with the reform of its public administration in 1997 upon the basis of the Strategy of Reform of the Public Administration. This only anticipated the acceptance of a new legal framework for the organisation and operation of public administration. As a result, the government of the Republic of Slovenia actively intervened, particularly after 2000 in various areas of renewal of public administration, which has already showed good results. In order to promote and attract foreign direct investments in April 2001 the government of Slovenia established a committee for abolishing administrative barriers to investment and developed a special plan to achieve this (the so-called Anti-bureaucratic programme).

Reorganisation of state administration operations produces two important goals in the strategy of reform: greater productivity and better quality of service (Setnikar-Cankar, Andoljšek, 2003). The state administration in countries in transition represents the core of the public sector and the information mechanism of the state, which notes, collects and processes information and, on their basis, prepares decisions for the needs of the entire system. All state bodies operate and make decisions based upon these principles - from the legislative level, to the executive (governmental) level and to the administrative level. If the state administration is not operating properly, its deficiencies necessarily reflect on the whole system. This explicitly means that all developmental projects must include all viewpoints of reforms: legal, administrative, organisational, economic, financial and informational. Only the integrity of approach ensures the best results. In economy, the project ways of integral solving of outstanding issues have been a long-lasting practice. The best results have also been attained in this area, which have impacted on the economic results of business operations in a positive way.

A thorough renewal of public administration, respectively the removal of administrative obstacles, was a decision also made by the government of the Republic of Slovenia. Thus, together with the guidance of stable and developmental public finance policies, it has demanded a continued strengthening of economic competitiveness and a more effective, people friendly administration. 

intervene in:

Exceptionally important is political consensus and support for the program which will, in the future,

- $\quad$ reducing or eliminating growth of the share of public consumption in the GDP,

- $\quad$ increasing the effectiveness of civil servants (analyses show large differences among employees, up to a ratio of $1: 10$ in issuing administrative decisions),

- $\quad$ decreasing the number of employees in the public sector (additional education is needed for this step),

- $\quad$ improved utilisation of state assets,

- $\quad$ improved co-operation with civil society and its inclusion in the preparation of regulations.

The regulation on the manner of operation, as a combination of good practices of individual administrative bodies, anticipates procedures for assessing the quality: surveys to determine customer satisfaction, the introduction of an informer, a book of complaints and praise, as well as informing customers of the status of procedures. Quality in public administration is ascertained through the introduction of various standards of quality, particularly with the standards of ISO and the model of business excellence CAF.

In the first half of 2002, all basic laws had been adopted: the Civil Servants Act, the Public Administration Act, the Public Agencies Act, the Inspection Act, the Salary System in the Public Sector Act.

The Civil Servants Act anticipates or introduces some institutes which have been present in the private sector for a long time:

- the transfer of public employees,

- determination of the effectiveness/ineffectiveness of civil servants,

- a career system (promotion and demotion),

- $\quad$ an enduring learning process ("a learning administration").

All these acts should have an influence on (Črešnar-Pergar, 2002) :

- the decrease in the number of bodies composing ministries and government offices,

- the transfer of tasks to public agencies,

- $\quad$ the transfer of public tasks to private business operators,

- the privatisation of public companies and institutions,

- a transparent system for recruitment and promotion.

The regulatory environment is rigid and a number of bureaucratic obstacles, particularly complicated and long lasting administrative procedures are suffocating entrepreneurial initiatives. Within normative regulations quite a number of demands and regulations have accumulated. The program for eliminating administrative obstacles is aimed at simplifying procedures, eliminating unnecessary procedures, merging of procedures (i.e. merging the location permit and the building permit), and shorting procedures and their deadlines. In conjunction with this, the government of the Republic of Slovenia, in 2003, adopted restrictions for new employment in the public sector.

Only those exceptionally qualified employees together with experienced state officials can provide a more dynamic administration. Through special programs, schooling is made available to the most perspective of public employees at respected foreign and national universities.

Results of e-administration can be divided into two groups (Vintar, 2002):

- $\quad$ internal, e.g. the co-ordination of public records and

- $\quad$ external, e.g. greater accessibility to electronic administrative services for citizens and enterprises, access to public information for various users and establishment of a dialogue with the private sector and civil society 
(e-democracy), the project Uniform web page of administrative units (drafting of a catalogue of life circumstances).

Information technology is essential for some changes but insufficient for a comprehensive reform of public administration. There must follow financial and organisational factors that affect the rationality of operations and assure their efficient function. But this is not enough; there should also be a coordinated effort right across the public sector. Often the problem is lies in resistance from bureaucrats, who may prefer to maintain the status quo. This means that reforms should include changing mentalities and behaviours of public servants, in addition to bureaucratic, technological and institutional changes. This takes time as well as strong and lasting political commitment.

The problem when faced with administrative barriers is that we mainly focus on the bureaucratic, technological and institutional aspects of administrative procedures. The variations in administrative costs could be explained by structural factors such as the political regime, the level of corruption, the degree of openness, the public sector wage policy and the legal system in use. Moreover, average salaries do influence administrative costs, thus supporting the argument that low paid bureaucrats are less assiduous in dealing with investors' requests. These correlations suggest that administrative reforms need to be incorporated into the broader agenda of reforms such as trade and financial liberalisation and the fight against corruption.

\section{OPERATIONAL INDICATORS}

Increasing the competence of operations and improving quality requires evaluation of public sector working. One of the goals of various programmes is to develop procedures for monitoring, supervising and evaluating operations. The extent and quality of procedures performed is the basis for the acquisition of funding of organisational units, number of employees, equipment and other resources. Indicators must represent those assessment elements of users and providers of services assessed as essential for competent operations and quality of services.

Measuring efficiency and performance of public sector organisations is very demanding. The goal of private enterprise is financial effects (profit or capital yield) so they possess an arsenal of financial indicators complying with accountancy practice and are common everywhere. Measuring in non-profit making organisations is more difficult. These organisations were not established to produce financial effects but to provide services. The introduction of concepts of efficiency and performance measurement is therefore not the same in the public sector as in the private sector. Standards with regard to outcome in the public sector differ from those in the private sector, being more complex (Halachmi, 1992). Using only financial indicators in the public sector is not good and other standpoints must be considered: uniformity, equal access to services, quality of the social component and mostly results, meaning increase in welfare (Žurga, 2000).

The quality of services in the public sector is as important as it is in the private sector. There is however a separation of quality of services or product in the public sector and its provision to the user. The basic measure of product quality is customer satisfaction. Services must comply with their professional definition. The following indicators of service quality are possible - correctness, timeliness, accessibility, safety, friendliness, simplicity and understandability.

Indicators for establishing quality of services must be linked to standards or goals. They must be built into a system together with standards, goals and feedback information.

The procedure starts with a clear definition of activities, their component parts, results and consequences. They are defined with the goal for which an indicator is chosen (e.g. cost reduction, shortening waiting times, increasing competence of graduates, etc.). Selected indicators compare different forms of assessment and provide information on results achieved.

The Faculty of Administration joined the development of budgetary indicators for Slovenian municipalities that provide full information to the public on the use of budgetary funds by Slovenian municipalities (http://www.vus.uni-lj.si/sib/vhod.htm). 
Control and monitoring of the results of the workings of the public sector in certain developing nations follow the realisations, the standpoints and approaches in developed democratic nations. The code of fiscal transparency, the European Charter and computer generated indicators on the performance of the public sector in Great Britain have greatly influenced the measurement of performance of Slovenian local self-government (http://www.auditcommission.gov.uk/ac2/NRfirst.htm).

In the public sector, particularly on the level of local communities, measurement of performance is difficult and challenging to present in absolute terms, unlike the business sector, as an example, through profits. A relative method of measuring performance is established in the public sector. The measure is usually relative (i.e. per conditional unit) and expressed in correlation to the results of similar groups through benchmarking. The rank a chosen unit achieves among comparable units is certainly one of the key criteria of its performance.

When designing the system of indicators, we used the basic definition of an indicator, understood as numerical information or user-directed message. Suitably formed information must be understandable to users, complete, accessible via a suitable medium and assist in the decision-making process.

It is apparent that operational indicators are needed from internal and external reasons for assessing the past and planning the future. Unit managers require information on achieving the extent of services and costs and the possibilities for motivating employees. Certain external institutions require reports on the working of organs and organisations to assess their operation against various criteria. Indicators allow better cooperation between organisations within the public sector as they provide a clear picture of the status and role of each organisation and its impact on other parts.

\section{CONCLUSION}

Globalisation impacts on a country and its administration with a series of economical, technological, cultural and ecological processes, which requires a modified institutional role of state administration.

Special attention is paid to introducing new public management in the public sector, especially in the area of public administration. Administrative regulations and public administration operation affects the extent and quality of mutual relations. The rigidity of the "bureaucracy" can prevent business cooperation of economic subjects and make more difficult the satisfaction of the needs of the population.

In May 2004 Slovenia joins the European Union. Data from the Office for organisation and development of public administration at the Ministry of Internal Affairs show that much has been achieved in the area of the legal framework and least in analysing the actual status of efficiency and performance in the public sector. (http://www.mnz.si/si/14.php).

In introducing a system of indicators to establish efficiency and performance it is necessary to take into account the peculiarities of the public sector and non-profit-making organisations. This is an environment where there is less management experience, profit orientation and project solving. Three participants exist in the public sector service users or customers, civil servants that deal with services and service providers (e.g. politicians). Theses three participating groups can have the same or different goals for a particular service in the public sector. There still prevails the conviction that the basic mission of non-profit-making organisations is the provision of services. The system of public management is set up in the foreground of organisational, financial or professional viewpoints and the satisfaction of users and payers of services. 


\section{REFERENCES}

1. Brezovšek, Marjan: Globalizacija in nova paradigma upravljanja. v Globalizacija in državna uprava. Fakulteta za družbene vede. (Globalisation and the new paradigm of management in the globalisation of public administration. Faculty of Social Science) Ljubljana. 2003. pages 5-8.

2. $\quad$ Črešnar-Pergar, Nevenka: Kako do racionalnejše uprave. IX. Dnevi slovenske uprave: zbornik referatov. Visoka upravna šola. The way to a more rationalised public administration - IX Slovene Public Administration Days. School of Public Administration). Portorož. 2002. pages 493-500.

3. Dunleavy, Patrick; Hood, Christopher: From Old Public Administration to New Public Management. Public Money and Management. 14 (1994), 2, pages 9-16.

4. Falconer, Peter; Public Administration and the New Public Management: Lessons from the UK experience. in Davies, Morton, et.al.: New State, New Millennium, New Public Management. Ljubljana: School of Public Administration. 1997. pages 67-83.

5. $\quad$ Giddens, Anthony: The Consequences of Modernity. Polity Press, Cambridge, 1990.

6. Halachmi, Ari: Evaluation research: Purpose and perspective. Public productivity handbook. New York. 1992. pages 213-226.

7. Morisset, J. and Neso, O. L.: Administrative Barriers to Foreign Investment in Developing Countries. Washington: World Bank. 2002.

8. Pikalo, Jernej: O diskurzu globalizacije in vlogi države v njem. v Brezovšek, Marjan, Haček, Miro: Globalizacija in državna uprava. Fakulteta za družbene vede. (The debate on globalisation and the role of the state in it - Brezovšek, Marjan, Haček, Miro: Globalisation and state administration. Faculty of Social Science). Ljubljana. 2003. pages 25-44.

9. Price Waddams, Catherine, Young, Alison: UK Utility Reform: Distributional Implications and Government Response. in Ugaz, Cecilia, Price Waddams Catherine: Utility Privatization and Regulation. Edward Elgar. Cheltenham, UK, Northampton, MA, USA. 2003. pages 101-124.

10. Setnikar-Cankar, Stanka, Pevcin, Primož: The influence of the state on the competitiveness of the economy the case of Slovenia. Fourth International Conference on Enterprise in Transition. Faculty of Economics.

Split. 2002.

11. Vintar, Mirko: Funkcionalna analiza državne uprave kot podlaga za njeno racionalizacijo in povečanje njene učinkovitosti. Komisija Vlade Slovenije za odpravo administrativnih ovir. (Functional analysis of state administration as a basis for its rationalisation and increasing its efficiency. Committee of the Government of the Republic of Slovenia for Eliminating Administrative Barriers). Ljubljana. 2002.

12. http://www.mnz.si/si/14.php

13. http://www.auditcommission.gov.uk/ac2/NRfirst.htm).

14. http://www.vus.uni-lj.si/sib/vhod.htm. 